\title{
Environmental stressors perceived by patients in the surgical intensive care unit and their level of satisfaction with nursing care
}

Follow this and additional works at: https://www.journal.acorn.org.au/jpn

Part of the Critical Care Nursing Commons, and the Perioperative, Operating Room and Surgical Nursing Commons

(c) (i)

This work is licensed under a Creative Commons Attribution 4.0 License.

\section{Recommended Citation}

Karaer, Hacer and Ozsaker, Esma (2021) "Environmental stressors perceived by patients in the surgical intensive care unit and their level of satisfaction with nursing care," Journal of Perioperative Nursing: Vol. 34 : Iss. 4 , Article 5.

Available at: https://doi.org/10.26550/2209-1092.1151

https://www.journal.acorn.org.au/jpn/vol34/iss4/5

This Article is brought to you for free and open access by Journal of Perioperative Nursing. It has been accepted for inclusion in Journal of Perioperative Nursing by an authorized editor of Journal of Perioperative Nursing. 


\section{Authors}

Hacer Karaer

MSc, RN

Ministry of Health

Kutahya University of Health Sciences Evliya Celebi Education and Research Hospital, Kutahya, Turkey

\section{Esma Ozsaker}

PhD, RN

Faculty of Nursing, Surgical Nursing

Department, Ege University, Izmir, Turkey

\section{Corresponding author}

Hacer Karaer

PhD, RN

Ministry of Health

Kutahya University of Health Sciences Evliya Celebi Education and Research Hospital, Kutahya, Turkey

hacerkaraer@yahoo.com

\title{
Environmental stressors perceived by patients in the surgical intensive care unit and their level of satisfaction with nursing care
}

\author{
Abstract \\ Purpose: The purpose of this study was to determine environmental stressors \\ perceived by patients in the surgical intensive care unit and their level of \\ satisfaction with nursing care.
}

Design: A descriptive cross-sectional study design was used in this study.

Methods: This study was conducted between January 2019 and June 2019 with 120 patients who were hospitalised in the surgical intensive care unit. Data collection was via a patient information form, the Intensive Care Unit Environmental Stressor Scale (ICUESS) and the Experiences of Nursing Care Scale (ENCS) component of the Newcastle Satisfaction with Nursing Scales (NSNS).

Findings: The mean ICUESS score was found to be $76.30 \pm 11.18$. The main stressors perceived by the patients in the surgical intensive care unit were being in pain, being thirsty and sleeplessness. The ENCS mean score was 81.05 \pm 9.03 .

Conclusion: The mean score of the ICUESS of patients was moderate and the mean score of the ENCS was good. There was a statistically significant, negative and moderate correlation between the ICUESS score and the ENCS score.

Keywords: surgery, nursing care, intensive care unit, patient satisfaction, environmental stressor

\section{Introduction}

Being sick and being hospitalised causes anxiety and stress in the individual ${ }^{1,2}$. Patients in the intensive care unit (ICU) experience more of this anxiety and stress ${ }^{3}$ due to the physical environment of the ICU, the technological devices used, the way the ICU functions and the special treatment methods applied. While technological developments increase treatment opportunities and the quality of life for patients, environmental stressors can adversely affect the quality of life $\mathrm{e}^{4}$. The opportunities for diagnosis, follow-up and treatment of lifethreatening diseases have increased, thanks to developments and changes in health care technology, but patients have been exposed to negative environmental stressors during their stay in intensive care?. Stressors in the intensive care environment are defined as physical, physiological and environmental ${ }^{5,6}$. It is known that environmental factors play a large role in increasing or decreasing the patient's stress ${ }^{4,7}$.

Environmental stressors that patients frequently encounter are: invasive interventions, deterioration of the 
perception of day/night, extreme heat or cold, fear/anxiety, being separated from the family, inability to fulfil their role in the family, loneliness, lack of privacy, disturbing images and smells $s^{2,6,8-10}$. Nurses need to identify the stressors perceived by patients, take precautions against the stressors, evaluate patient reactions to stressful situations and plan care accordingly 1,4,11.

Excessive noise, light, excessive mobility or the opposite, inactivity and monotonous sounds in the intensive care unit cause psychosocial problems (such as sensory deprivation or overload) in patients ${ }^{5,12}$. Health care professionals knowing the environmental factors that cause stress in patients treated in the ICU and taking necessary precautions in this regard will positively affect the healing process of the patients ${ }^{12}$.

It is recommended that environmental stressors in the ICU are identified in order to minimise them (for example, by providing patient comfort and privacy, reducing light and noise and relieving pain), and to enable patients to cope with the stress factors they experience 4 . Also, it is stated that patients having bad experiences in the ICU reduces their satisfaction with nursing care $^{11}$. Accounting for the factors affecting satisfaction with nursing care enables patients to adapt to treatment, feel valued and increase their health-enhancing behaviors ${ }^{13}$. Determining the environmental stressors perceived by patients in the intensive care unit and their effects on the patients is important in terms of reducing the negative effects of the ICU and planning initiatives and nursing care to create an appropriate environment. This research was conducted to determine the environmental stressors perceived by patients in the surgical ICU and their satisfaction levels concerning nursing.
The following research questions were developed.

1. What are the environmental stressors perceived by patients in the surgical intensive care unit?

2. What is the level of satisfaction of patients in terms of nursing in the surgical care unit?

3. Do environmental stressors affect patients' satisfaction with nursing care?

\section{Methods}

\section{Design}

In this descriptive cross-sectional study, the sample comprised 120 patients hospitalised in surgical ICUs between January and June 2019. The cardiovascular surgery ICU had an area of $170 \mathrm{~m}^{2}$ and a total of nine beds in ward style. The general surgery ICU had an area of $46 \mathrm{~m}^{2}$ and a total of four beds in ward style.

\section{Study population}

Patients who were over the age of 18 , had no communication problems, were conscious, had been in the ICU for 24-72 hours and volunteered to participate in the study were included in the scope of the research. As delirium develops after 72 hours in the ICU, patients whose stay exceeded this period were not included in the study.

\section{Data collection}

Data was collected using a personal information form, the Intensive Care Unit Environmental Stressors Scale (ICUESS) and the Newcastle Satisfaction with Nursing Scales (NSNS).

\section{Personal information form}

The form was prepared by the researcher as a result of the literature review and consisted of 25 questions about sociodemographic characteristics and illness.
Intensive Care Unit

\section{Environmental Stressor Scale (ICUESS)}

This tool was developed by Ballard ${ }^{14}$ to identify the stressors perceived by patients treated in intensive care units and its validity and reliability in Turkish were determined by Aslan and Cinar $^{15}$. The scale is a four-point Likert-type scale consisting of 42 items. The minimum score to be obtained from the scale is 42 and the maximum is 168 points. Higher scores indicate higher rates of patient exposure to environmental stressors ${ }^{12,15,16}$. In the study conducted by Aslan and Cinar the Cronbach alpha coefficient was found to be $0.94^{14}$ whereas in this study the Cronbach alpha coefficient was found to be 0.72 .

\section{Newcastle Satisfaction with Nursing Scale (NSNS)}

This tool was developed by Thomas et al.17 and its validity and reliability in Turkish was conducted by Uzun $(2003)^{18}$. The NSNS consists of two scales - the Experiences of Nursing Care Scale (ENCS) and the Satisfaction with Nursing Care Scale (SNCS). These scales can be applied together or separately. In this research, only the ENCS was applied as the items in this scale were considered to be more suitable for intensive care patients. The ENCS is a seven-point Likert-type scale consisting of 26 items. After the scores of all items in the scale are added, they are converted to 100 and an evaluation is made over 0 to 100 points. A total score of 100 indicates that the experience of nursing care is at the best level ${ }^{18,19}$. In the study conducted by Uzun the Cronbach alpha coefficient was found to be $0.75^{18}$. In this study, the Cronbach alpha coefficient was found to be 0.89 . 


\section{Implementation of research}

Between January and June 2019, patients who met the research criteria were informed about the purpose of the research. Researchers collected data using face-to-face interviews after the patients were taken from the ICU to the clinic (i.e. when patients completed their ICU journey). Interviews lasted an average of 15 minutes.

\section{Data analysis}

The data obtained from the research was analysed using the software SPSS for Windows. The results were expressed as number (percentage), mean and standard deviation $( \pm s d)$. Since the data did not show normal distribution, continuous measurements were evaluated with nonparametric tests; Spearman correlation, Mann Whitney $\mathrm{U}$ and the Kruskal-Wallis test were used. The value of $\mathrm{P}<0.05$ was considered the statistical significance limit.

\section{Ethical considerations}

The research was approved by the Medical Research Ethics Committee. Written permission was obtained from the institution where the study was carried out. Informed consent was obtained from all individual participants included in the study. This study was performed according to the Helsinki Declaration.

\section{Results}

\section{Patient descriptive characteristics}

The average age of patients participating in the study was 58.24 13.53 ( $\min .18, \max .75$ ); 65.8 per cent of the patients were male, 79.2 per cent were married, 60.8 per cent were literate or graduated from primary school, 79.2 per cent had a chronic disease,
75.8 per cent were taking medication (e.g. analgesics and antihypertensives for chronic disease), and 60.8 per cent had not been admitted to the ICU before. Regarding type of ICU, 63.3 per cent of patients were in the cardiovascular surgery ICU and 46.7 per cent in general surgery ICU. The average length of stay in the ICU was $26.96 \pm 10.67$ hours and 69.1 per cent of patients were connected to mechanical ventilation with the average period of mechanical ventilation being $6.97 \pm 3.17$ hours. Relatives of 95.0 per cent of patients came to visit the patient in the ICU. The treatment and care received was evaluated as good by 55.8 per cent of patients and as very good by 41.7 per cent.

\section{ICUESS and ENCS scores}

Table 1 shows the mean scores for stressors on the ICUESS. The total average ICUESS score was $76.30 \pm 11.18$ and the top three stressors perceived by participating patients were pain (2.94 \pm 0.99$)$, not being able to drink water $(2.79 \pm 1.32)$ and not being able to sleep $(2,75 \pm 1,18)$.

No statistically significant difference was found between any of the descriptive characteristics and the total ICUESS or ENCS score $(p>0.05)$. (See Table 2.)

While no statistically significant difference was found between ICUESS or ENCS scores and any of the patient characteristics $(p>0.05)$, there was a statistically significant difference between the clinic types and the ICUESS total score. The total ICUESS score averages of the patients in the cardiovascular surgery ICU were higher than those of patients in the general surgery ICU $(p<0.05)$. (See Table 3.)

A moderate and statistically significant negative correlation was found between the ICUESS total score and ENCS total score $\left(r_{\mathrm{s}}=-0.376\right.$, $p=0.001)$. A statistically significant and rather weak negative relationship was found between patient age and ENCS total score ( $r s=-0.190, p=0.038$ ). No statistically significant correlation was found between either length of stay in the ICU or duration of mechanical ventilation and the total scores of ICUESS and ENCS ( $p>0.05)$. (See Table 4.)

\section{Discussion}

Nursing care involves treating the patient as a whole with their physical, psychological and social aspects. However, since the condition of patients in the ICU is critical and requires urgency, physiological care can be prioritised and psychological care of patients can be ignored ${ }^{20}$. However, determining the presence and level of influence of stressors that can cause anxiety, fear, depression and negative health behaviors in the care and rehabilitation of patients during the intensive care process is important in determining care need ${ }^{20,21}$.

In this study, the average ICUESS score of patients was $76.30 \pm 11.18$. This result shows that the participating patients' perception of stressors was below average. Intensive care patients' low perception of stress may be due to an inability to remember the surrounding events clearly, not wanting to remember the experience they went through and not wanting to come across as a complaining patient ${ }^{16}$.

The averages of total ICUESS scores in similar studies were examined and found to be $69.26 \pm 21.84$ by Tezcan Karadeniz and Kanan ${ }^{3}, 79.9 \pm 31.3$ by Candan Donmez et al.16, 86.20 \pm 15.61 by Hweidi and $\mathrm{Nizamli}^{10}, 86.70 \pm 2.73$ by Yaman Aktaș et al. ${ }^{6}, 110.22 \pm 15.64$ by Şahin and Köçkar ${ }^{20}$ and 128.32ะ16.37 by Gencer and Karakoç-Kumsar?. 
Table 1: Mean scores for stressors on the Intensive Care Unit Environmental Stressor Scale (ICUESS) as rated by patients

\begin{tabular}{|c|c|c|}
\hline & Stressors (1-4 points) & Mean \pm SD \\
\hline 1 & Being tied down by tubes & $2.47 \pm 1.20$ \\
\hline 2 & $\begin{array}{l}\text { Not having nurses introduce } \\
\text { themselves }\end{array}$ & $1.64 \pm 0.93$ \\
\hline 3 & $\begin{array}{l}\text { Having nurses be in too much of a } \\
\text { hurry }\end{array}$ & $1.09 \pm 0.31$ \\
\hline 4 & Being thirsty & $2.79 \pm 1.32$ \\
\hline 5 & $\begin{array}{l}\text { Having your blood pressure taken } \\
\text { often }\end{array}$ & $1.01 \pm 0.18$ \\
\hline 6 & Uncomfortable bed or pillow & $1.45 \pm 0.79$ \\
\hline 7 & Hearing the telephone ring & $1.26 \pm 0.68$ \\
\hline 8 & $\begin{array}{l}\text { Frequent physical exams by doctors or } \\
\text { nurses }\end{array}$ & $1.05 \pm 0.31$ \\
\hline 9 & Having strange machines around you & $1.67 \pm 0.88$ \\
\hline 10 & $\begin{array}{l}\text { Feeling nurses are watching the } \\
\text { machines closer than watching you }\end{array}$ & $1.07 \pm 0.34$ \\
\hline 11 & $\begin{array}{l}\text { Hearing the buzzers and alarms from } \\
\text { the machinery }\end{array}$ & $1.53 \pm 0.87$ \\
\hline 12 & Nurses and doctors talking too loudly & $1.56 \pm 0.95$ \\
\hline 13 & Having to wear oxygen & $2.00 \pm 1.04$ \\
\hline 14 & Missing your husband or wife & $2.73 \pm 1.09$ \\
\hline 15 & Not having treatment explained to you & $2.29 \pm 1.11$ \\
\hline 16 & $\begin{array}{l}\text { Hearing you heart monitor alarm go } \\
\text { off }\end{array}$ & $1.49 \pm 0.85$ \\
\hline 17 & $\begin{array}{l}\text { Having nurses constantly doing things } \\
\text { around your bed }\end{array}$ & $1.06 \pm 0.25$ \\
\hline 18 & Having tubes in your nose or mouth & $2.28 \pm 1.18$ \\
\hline 19 & Not knowing what time it is & $2.05 \pm 1.30$ \\
\hline 20 & Hearing other patients cry out & $2.54 \pm 1.25$ \\
\hline 21 & $\begin{array}{l}\text { Having men and women in the same } \\
\text { room }\end{array}$ & $1.30 \pm 0.74$ \\
\hline
\end{tabular}

\begin{tabular}{|c|c|c|}
\hline & Stressors (1-4 points) & Mean $\pm S D$ \\
\hline 22 & $\begin{array}{l}\text { Only seeing family and friends for a } \\
\text { few minutes each day }\end{array}$ & $1.19 \pm 1.11$ \\
\hline 23 & $\begin{array}{l}\text { Not knowing when to expect things to } \\
\text { be done }\end{array}$ & $2.66 \pm 0.50$ \\
\hline 24 & Being awakened by nurses & $1.76 \pm 0.93$ \\
\hline 25 & Unfamiliar and unusual noises & $1.17 \pm 0.52$ \\
\hline 26 & $\begin{array}{l}\text { Watching treatment being given to } \\
\text { other patients }\end{array}$ & $2.00 \pm 1.10$ \\
\hline 27 & $\begin{array}{l}\text { Having to look at the pattern of tiles/ } \\
\text { holes in the ceiling }\end{array}$ & $2.53 \pm 1.22$ \\
\hline 28 & Not being able to sleep & $2.75 \pm 1.18$ \\
\hline 29 & $\begin{array}{l}\text { Not being able to move your hands or } \\
\text { arms because of intravenous (IV) lines }\end{array}$ & $1.86 \pm 0.62$ \\
\hline 30 & $\begin{array}{l}\text { Being aware of unusual smells around } \\
\text { you }\end{array}$ & $1.08 \pm 0.37$ \\
\hline 31 & Having lights on constantly & $2.54 \pm 1.18$ \\
\hline 32 & Being in pain & $2.94 \pm 0.99$ \\
\hline 33 & $\begin{array}{l}\text { Seeing intravenous (IV) bags over your } \\
\text { head }\end{array}$ & $1.11 \pm 0.41$ \\
\hline 34 & Being stuck with needle & $2.09 \pm 0.79$ \\
\hline 35 & Not knowing where you are & $2.03 \pm 1.32$ \\
\hline 36 & $\begin{array}{l}\text { Having nurses use words you cannot } \\
\text { understand }\end{array}$ & $1.08 \pm 0.33$ \\
\hline 37 & Not being in control of yourself & $1.14 \pm 0.43$ \\
\hline 38 & Not knowing what day it is & $2.23 \pm 1.34$ \\
\hline 39 & Being bored & $2.53 \pm 1.24$ \\
\hline 40 & Having no privacy & $2.07 \pm 1.15$ \\
\hline 41 & Being cared for by unfamiliar doctors & $1.03 \pm 0.22$ \\
\hline 42 & $\begin{array}{l}\text { Being in a room which is too hot or } \\
\text { cold }\end{array}$ & $2.02 \pm 1.23$ \\
\hline \multicolumn{2}{|c|}{ Total score } & $76.30 \pm 11.18$ \\
\hline
\end{tabular}


Table 2: The average distributions of Intensive Care Unit Environmental Stressor Scale (ICUESS) and Experiences of Nursing Care Scale (ENCS) scores according to the descriptive characteristics of the patients

\begin{tabular}{|c|c|c|c|c|c|}
\hline \multirow[b]{2}{*}{ Patient characteristics } & \multirow[b]{2}{*}{$\mathrm{n}(\%)$} & \multicolumn{2}{|c|}{ ICUESS } & \multicolumn{2}{|c|}{ ENCS } \\
\hline & & $X \pm S S$ & $\begin{array}{l}\text { Statistical } \\
\text { comparison }\end{array}$ & $X \pm$ SS & $\begin{array}{l}\text { Statistical } \\
\text { comparison }\end{array}$ \\
\hline \multicolumn{3}{|l|}{ Gender } & $Z=-0.244 P=0.808$ & & $Z=-1.453 P=0.146$ \\
\hline - female & $41(34.2)$ & $80.75 \pm 8.94$ & & $78.00 \pm 10.41$ & \\
\hline - male & $79(65.8)$ & $81.20 \pm 9.13$ & & $75.41 \pm 11.52$ & \\
\hline \multicolumn{3}{|l|}{ Marital status } & $Z=-1.616 P=0.106$ & & $Z=-1.461 P=0.144$ \\
\hline - married & $95(79.2)$ & $81.87 \pm 8.33$ & & $75.38 \pm 10.36$ & \\
\hline - single & $25(20.8)$ & $77.91 \pm 10.94$ & & $79.76 \pm 13.54$ & \\
\hline \multicolumn{3}{|l|}{ Educational status } & $K W=9.519 P=0.059$ & & $K W=5.551 P=0.235$ \\
\hline - not literate & $15(12.5)$ & $80.03 \pm 5.44$ & & $81.66 \pm 11.43$ & \\
\hline - primary school & $73(60.8)$ & $80.83 \pm 9.45$ & & $76.21 \pm 10.89$ & \\
\hline - secondary school & $12(10.0)$ & $87.40 \pm 6.29$ & & $72.83 \pm 8.61$ & \\
\hline - high school & $13(10.8)$ & $77.68 \pm 11.25$ & & $75.00 \pm 12.69$ & \\
\hline - university & $7(5.8)$ & $80.84 \pm 6.46$ & & $74.00 \pm 13.65$ & \\
\hline \multicolumn{3}{|l|}{ Occupation } & $K W=4.073 P=0.396$ & & $K W=2.830 P=0.587$ \\
\hline - housewife & $37(30.8)$ & $80.99 \pm 9.17$ & & $77.27 \pm 10.32$ & \\
\hline - officer & $4(3.3)$ & $79.53 \pm 3.65$ & & $79.75 \pm 11.92$ & \\
\hline - worker & $38(31.7)$ & $81.56 \pm 10.12$ & & $74.81 \pm 10.95$ & \\
\hline - retired & $15(12.5)$ & $83.00 \pm 6.52$ & & $75.40 \pm 14.28$ & \\
\hline - other & $26(21.7)$ & $79.50 \pm 9.20$ & & $72.07 \pm 11.17$ & \\
\hline \multicolumn{3}{|l|}{ Smoking status } & $K W=1.652 P=0.408$ & & $K W=1.794 P=0.408$ \\
\hline - still smoking & $14(11.7)$ & $83.83 \pm 6.66$ & & $73.42 \pm 7.25$ & \\
\hline - never smoked & $46(38.3)$ & $80.08 \pm 8.09$ & & $77.73 \pm 12.24$ & \\
\hline - quitted smoking & $60(50.0)$ & $81.14 \pm 10.11$ & & $75.86 \pm 11.06$ & \\
\hline \multicolumn{3}{|l|}{ Place of residence } & $K W=1.273 P=0.529$ & & $K W=0.707 P=0.702$ \\
\hline - province & $62(51.7)$ & $80.31 \pm 10.33$ & & $76.75 \pm 11.37$ & \\
\hline - district & $37(30.8)$ & $82.92 \pm 4.96$ & & $72.02 \pm 10.51$ & \\
\hline - village & $21(17.5)$ & $79.93 \pm 10.29$ & & $77.19 \pm 12.05$ & \\
\hline \multicolumn{3}{|l|}{ Household members } & $K W=4.116 P=0.249$ & & $K W=5.305 \quad P=0.151$ \\
\hline - patient alone & $16(13.3)$ & $78.46 \pm 12.41$ & & $78.62 \pm 15.44$ & \\
\hline - patient and spouse & $57(47.5)$ & $82.04 \pm 8.21$ & & $74.28 \pm 10.64$ & \\
\hline - patient and children & $12(10.0)$ & $77.88 \pm 7.45$ & & $81.91 \pm 10.24$ & \\
\hline $\begin{array}{l}\text { - patient and spouse and } \\
\text { children }\end{array}$ & $35(29.2)$ & $81.71 \pm 8.93$ & & $76.60 \pm 9.54$ & \\
\hline
\end{tabular}

Notes: Z= Mann Whitney U, KW= Kruskal-Wallis Test, 
Table 3: The average distributions of Intensive Care Unit Environmental Stressor Scale (ICUESS) and Experiences of Nursing Care Scale (ENCS) scores according to patient characteristics and clinic type

\begin{tabular}{|c|c|c|c|c|c|}
\hline \multirow[b]{2}{*}{ Characteristics } & \multirow[b]{2}{*}{$n(\%)$} & \multicolumn{2}{|c|}{ ICUESS } & \multicolumn{2}{|c|}{ ENCS } \\
\hline & & $\mathrm{X} \pm \mathrm{SS}$ & $\begin{array}{c}\text { Statistical } \\
\text { comparison }\end{array}$ & $\mathrm{X} \pm \mathrm{SS}$ & $\begin{array}{l}\text { Statistical } \\
\text { comparison }\end{array}$ \\
\hline \multicolumn{3}{|l|}{ Clinic } & $Z=-2.169 P=0.030 *$ & & $Z=-0.594 \quad P=0.553$ \\
\hline - cardiovascular & $76(63.3)$ & $77.90 \pm 11.00$ & & $81.80 \pm 7.93$ & \\
\hline · general surgery & $44(36.7)$ & $73.52 \pm 11.05$ & & $79.75 \pm 10.64$ & \\
\hline \multicolumn{3}{|l|}{ Chronic disease } & $Z=-0.469 P=0.639$ & & $Z=-1.746 P=0.081$ \\
\hline - yes & $95(79.2)$ & $76.56 \pm 11.17$ & & $80.75 \pm 8.35$ & \\
\hline$\cdot$ no & $25(20.8)$ & $75.28 \pm 11.38$ & & $82.19 \pm 11.39$ & \\
\hline \multicolumn{3}{|l|}{ Taking medication } & $Z=-0.098 \quad P=0.922$ & & $Z=1.35 \quad P=0.174$ \\
\hline - yes & $91(75.8)$ & $76.28 \pm 11.15$ & & $80.82 \pm 8.58$ & \\
\hline$\cdot$ no & $29(24.2)$ & $76.34 \pm 11.47$ & & $81.75 \pm 10.44$ & \\
\hline \multicolumn{3}{|c|}{ Previous hospitalisation } & $Z=-0.847 \quad P=0.397$ & & $Z=-0.663 \quad P=0.508$ \\
\hline - yes & $103(85.8)$ & $76.67 \pm 11.17$ & & $81.50 \pm 8.17$ & \\
\hline - no & $17(14.2)$ & $74.00 \pm 11.26$ & & $78.31 \pm 13.08$ & \\
\hline \multicolumn{3}{|c|}{ Previous admission to ICU } & $Z=-1.167 P=0.243$ & & $Z=-0.608 \quad P=0.543$ \\
\hline - yes & $47(39.2)$ & $74.76 \pm 11.48$ & & $81.92 \pm 7.85$ & \\
\hline$\cdot$ no & $73(60.8)$ & $77.28 \pm 10.94$ & & $80.49 \pm 9.72$ & \\
\hline \multicolumn{3}{|c|}{ Oral nutritional status } & $Z=-0.219 P=0.827$ & & $Z=-0.261 P=0.794$ \\
\hline - yes & $110(91.7)$ & $76.35 \pm 11.12$ & & $81.01 \pm 9.34$ & \\
\hline$\cdot$ no & $10(8.3)$ & $75.70 \pm 12.41$ & & $81.48 \pm 4.70$ & \\
\hline \multicolumn{3}{|c|}{ Experienced mechanical ventilation before } & $Z=-0.245 P=0.248$ & & $Z=-0.162 P=0.334$ \\
\hline - yes & $83(69.1)$ & $77.10 \pm 10.89$ & & $80.33 \pm 9.69$ & \\
\hline$\cdot$ no & $37(30.8)$ & $74.48 \pm 11.73$ & & $82.65 \pm 7.19$ & \\
\hline \multicolumn{3}{|l|}{ Had visitors } & $Z=-0.849 P=0.396$ & & $Z=-0.139 P=0.890$ \\
\hline - yes & $114(95.0)$ & $76.54 \pm 11.25$ & & $81.00 \pm 9.20$ & \\
\hline$\cdot$ no & $6(5.0)$ & $71.66 \pm 9.22$ & & $82.05 \pm 5.22$ & \\
\hline
\end{tabular}

Note: Z= Mann Whitney U 
Table 4: The relationship between patient age, length of stay in ICU, duration of mechanical ventilation, ICUESS total score and ENCS total score

\begin{tabular}{|c|c|c|c|c|}
\hline & \multicolumn{2}{|c|}{$\begin{array}{l}\text { ICUESS total score } \\
(76.30 \pm 11.18)\end{array}$} & \multicolumn{2}{|c|}{$\begin{array}{l}\text { ENCS total score } \\
\quad(81.05 \pm 9.03)\end{array}$} \\
\hline & $r_{s}$ & $P$ & $r_{s}$ & $\mathrm{P}$ \\
\hline ICUESS total score & & & -0.376 & $0.001^{*}$ \\
\hline Age & 0.150 & 0.101 & -0.190 & $0.038^{*}$ \\
\hline Length of stay in ICU (hours) & 0.058 & 0.528 & -0.103 & 0.264 \\
\hline Duration of mechanical ventilation (hours) & 0.098 & 0.379 & 0.078 & 0.482 \\
\hline
\end{tabular}

Notes: $r_{s}=$ Spearman'sRho, ${ }^{*} p<0.05$

These results show that patients receiving treatment in the ICU perceive different levels of stress. The difference between studies is thought to be due to the fact that studies have been conducted in different intensive care units and involved patients with different diagnoses.

In this study, no statistically significant relationship was found between the ICUESS total score and any of the descriptive patient characteristics (age, gender, marital status, educational status, occupation, smoking status, place of residence and household members). There was also no statistically significant relationship between the ICUESS total score and other characteristics investigated (whether or not the patient had chronic disease, took medication, had previously been hospitalised, had previously been admitted to the ICU, could take oral nutrition, had previous experience of mechanical ventilation or had visitors). In addition, no statistically significant relationship was found between ICUESS total score and length of stay in ICU or duration of mechanical ventilation. In contrast, in Şahin and Köçkar's study on the environmental stressors perceived by patients hospitalised in the surgical ICU ${ }^{20}$, the researchers found that age (specifically the 31-50 age range), educational status, marital status, absence of chronic illness, length of stay in the ICU and patient status regarding previous admission to the ICU significantly affected the scale's average score. Research into cardiovascular surgery ICUs conducted by Yaman Aktaș et al. ${ }^{6}$, determined that age, gender, marital status and educational status did not significantly affect the average total score.

In this research, the averages of the total ICUESS score of the patients in the cardiovascular surgery ICU were higher than for the patients in the general surgery ICU $(p<0.05)$. In cardiovascular surgery patients, the symbolic meaning and importance of the heart and the fear of intervention with the heart cause fear of death, while the process of being connected to and disconnected from the mechanical ventilator, implantable cardiac defibrillators and incisions for catheters and drains increase the risk of anxiety ${ }^{22}$. The difference between the two clinics is thought to be due to these reasons.

In this study, the stressor with the highest mean score was "being in pain'. This is consistent with most other similar studies $3,6,8,16,20,23$. Factors that can cause pain in patients include the disease requiring intensive care, various invasive and non-invasive interventions, treatment and care initiatives, aspiration processes, dressing changes, prolonged inactivity and aspects of surgery - the operation area, its duration, characteristics and the type of incision - as well as patient transfer. Frequent pain is expressed by many patients in intensive care from mild to severe ${ }^{21,24}$. Sleep disturbance, anxiety and delirium may develop in patients due to increased release of endogenous catecholamine following painful inductions ${ }^{6}$. Pain is an important factor of suffering, affects the quality of life and jeopardises the physical and psychosocial state ${ }^{21}$; therefore, accurate diagnosis of pain by intensive care nurses and ensuring effective pain management can be useful in providing quality care ${ }^{6}$.

The stressor with the second highest mean score was 'not being able to drink water'. Thirst was perceived by patients as the most important stressor in the study by Gultekin et al. ${ }^{9}$ conducted in the general surgery and anesthesia and reanimation intensive care unit. In Sahin and Kockar's study ${ }^{20}$ and the study by Candan Donmez et $\mathrm{al}^{16}$, thirst was perceived as the third most important stressor. In the study of Zaybak and Cevik², thirst was 
determined as a low-level stressor ${ }^{2}$. It is thought that thirst is among the most highly rated stressors because patients hospitalised in the intensive care unit may be dehydrated due to the treatment process ${ }^{16}$.

In this study, the stressor with the third highest mean score was 'not being able to sleep'. Insomnia was found to be the second most important stressor by Yaman Aktas et al. ${ }^{6}$, and the fourth most important stressor by Candan Donmez et al. ${ }^{16}$. Factors that cause sleep disorders in patients include type and severity of the underlying disease, the pathophysiology of the acute disease, a patient's sleep habits, pain, exposure to light for 24 hours, noise, nursing interventions, unpleasant odors, mechanical ventilation incompatibility, aspiration, lying in a fixed position, loss of privacy, being away from the family and fear of death ${ }^{1,25}$. The noise level in the intensive care unit is twice that recommended by international guidelines ${ }^{26}$. Since sleep deprivation may prolong illness, delay recovery and cause confusion in intensive care patients, it is important to plan interventions to avoid sleep deprivation ${ }^{6}$. Given the stronger influence of environmental factors, the use of earplugs or sleep masks is recommended ${ }^{26}$.

The ENCS total score in this study was $81.05 \pm 9.03$ and the satisfaction was assessed as high. In many studies that evaluated the level of satisfaction of patients hospitalised in different clinics, it was found that patients were moderately to highly satisfied with the nursing care they received ${ }^{19,27,28}$. In this study, no statistically significant correlation ( $p>0.05$ ) was found between the total ICUESS score and either length of stay in the intensive care unit or the duration of being on the mechanical ventilation. Similarly, Dias et al. found that the length of stay in the ICU did not significantly affect the score of environmental stressors ${ }^{8}$. It has been suggested that prolonged stay in the intensive care unit may reduce patients' rating of environmental stressors as patients become accustomed to procedures and the intensive care environment ${ }^{20}$.

This study found that environmental stressors in the ICU negatively affected the level of satisfaction of patients with nursing care. Similarly, in the study conducted by Zengin et al. ${ }^{11}$, it was found that as the stressors increased the patients' perception of their ICU experience was negatively affected and satisfaction with nursing care decreased. ICUs provide services for treating individuals with medical and surgical diseases and contain a large number of technological devices. Patients in ICU face many physical and psychosocial stressors both because of the environment they are in and because of the surgical procedure they have had ${ }^{21}$. As a result, ICU patients face problems such as sleep disturbances, thirst, pain, inability to distinguish day and night, impaired perception, anxiety and fear ${ }^{2,20}$. Therefore, we think that as the environmental stressors perceived by the patient increase, their satisfaction with nursing care decreases.

Identifying environmental stressors in intensive care patients and making plans to eliminate those stressors will contribute positively to the treatment process.

\section{Limitations}

The results of this study cannot be generalised to the whole surgical ICU patient population in Turkey, as the study was conducted in only one state hospital.

\section{Conclusions}

This study found that the environmental stressor levels perceived by patients in the surgical ICU were below average. Being in pain was the stressor with the highest mean score, followed by not being able to drink water and not being able to sleep. Patient satisfaction levels with nursing care were found to be high. It was determined that environmental stressors in the intensive care unit negatively affected the satisfaction levels of patients with nursing care.

In line with these results, it is recommended that nurses thoroughly evaluate potential sources of patient stress in the ICU and take these stressors into account when arranging the patient's environment.

Also, nurses should constantly evaluate the level of satisfaction of patients with nursing care and make necessary plans to increase satisfaction.

\section{References}

1. Gencer A, Karakoç-Kumsar A. Yoğun bakım ünitesinde tedavi gören hastaların algıladıkları çevresel stresörlerin uyku kalitesine etkisi [The effect of perception of environmental stressors on sleep quality of patients treated in intensive care unit]. Online Türk Sağlık Bilimleri Dergisi [Online Turkish Journal of Health Sciences] 2020;(3):434-443. DOI: 10.26453/otjhs.694088.

2. Zaybak A, Çevik K. Yoğun bakım ünitesindeki stresörlerin hasta ve hemşireler tarafından algılanması [Stressors in the intensive care unit: Perceptions of patients and nurses]. Yoğun Bakım Dergisi [J Crit Intensive Care] 2015;6(1):4-9. DOI: 10.5152/dcbybd.2015.652.

3. Tezcan Karadeniz F, Kanan N. Reanimasyon yoğun bakim ünitesinde yatan hastalarin çevresel stresörlerden etkilenme durumlari [The effects of environmental stressors on patients in reanimation intensive care unit]. Yoğun Bakım Hemşireliği Dergisi [Journal of Intensive Care Nursing] 2019;(23)1:1-8.

4. Gezginci E, Goktas S, Orhan BN. The effects of environmental stressors in intensive care unit on anxiety and depression. Nurs Crit Care 2020;Sep:1-7. DOI: 10.1111/nicc.12553. 
5. Adsay E, Dedeli O. Yoğun bakım ünitesinden taburcu olan hastaların yoğun bakım deneyimlerinin değerlendirilmesi [Assessment of experiences of patients discharged from intensive care units]. Dahili ve Cerrahi Bilimler Yoğun Bakım Dergisi [Journal of Medical and Surgical Intensive Care Medicine] 2015;3(6):90-97. DOI: 10.5152/ dcbybd.2015.955.

6. Yaman Aktaș Y, Karabulut N, Yilmaz D, Özkan AS. Kalp damar cerrahisi yoğun bakım ünitesinde tedavi gören hastaların algıladıkları çevresel stresörler [Perception of environmental stressors by critical care patients treated in cardiovascular surgery intensive care unit]. Kafkas Tip Bilimler Dergisi [Kafkas Journal of Medical Sciences] 2015;5(3):81-86. DOI: 10.5505/ kjms.2015.29591.

7. Yeh J, Ostini R. The impact of health literacy environment on patient stress: A systematic review. BMC Public Health 2020;20:749. DOI: 10.1186/s12889-020-08649-x.

8. Dias Dde S, Resende MV, Diniz Gdo C. Patient stress in intensive care: Comparison between a coronary care unit and a general postoperative unit. Rev Bras Ter Intensiva [Brazilian Journal of Intensive Care] 2015;27(1):18-25. DOI: 10.5935/0103507X.20150005.

9. Gültekin Y, Özçelik Z, Akinci SB, Yorganci HK. Evaluation of stressors in intensive care units. Turk J Surg. 2018;34(1):5-8. DOI: 10.5152/ turkjsurg.2017.3736.

10. Hweidi IM, Nizamli FM. Stressors in intensive care units in Syria: Patients' perceptions. J Res Nurs 2014;1-13. DOI: 10.1177/1744987114524202.

11. Zengin N, Ören B, Üstündag $H$. The relationship between stressors and intensive care unit experiences. Nurs Crit Care 2019;1-8. DOI: 10.1111/nicc.12465.

12. Çinar S, Aslan F, Kurtoğlu T. Intensive care unit environmental stressors scale: Validity and reliability study. Yoğun Bakım Hemşireliği Dergisi [Journal of Intensive Care Nursing] 2011;15(2):61-6.
13. Cerit B. Level of patients' satisfaction with nursing care. Hacettepe Üniversitesi Hemşirelik Fakültesi Dergisi [Journal of Hacettepe University Faculty of Nursing] 2016;27-36

14. Ballard KS. Identification of environmental stressors for patients in a surgical intensive care unit. Issues Ment Health Nurs 1981;1:89-108

15. Aslan F, Cinar S. Perception of environmental stressors by patients treated in intensive care unit: Validity reliability study. Marmara University/Health Sciences Institute, 2010. istanbul.

16. Candan Donmez Y, Demir Korkmaz F, Gecit S. Yoğun bakım ünitesindeki çevresel stresörlerin hastalar tarafından algılanması [Perception of environmental stressors in intensive care unit by patients]. Turkiye Klinikleri J Nurs Sci. 2020;12(2):190-7. DOI: 10.5336/ nurses.2019-72255.

17. Thomas LH, McColl E, Priest J, Bond S, Boys RJ. Newcastle satisfaction with nursing scales: An instrument for quality assessments of nursing care. Qual Health Care 1996;5(2):67-72. DOI: 10.1136/qshc.5.2.67.

18. Uzun $\mathrm{O}$. The validity and reliability of Turkish Form of Newcastle Satisfaction with Quality of Nursing Care Scale. Turkish Journal of Nurses.2003;(54)2:15-24.

19. Ülgen T, Zeybekçi S, Ügur O. Bir üniversite hastanesi onkoloji kliniğinde yatan hastaların hemşire memnuniyeti ve etkileyen değişkenlerin incelenmesi [Hospitals on a university hospital oncology clinic nursing satisfaction and affecting of effective variables]. Turkiye Klinikleri J Nurs Sci. 2018;10(1):18-27. DOI: 10.5336/ nurses.2017-56254.

20. Şahin M, Köçkar C. Bir stresör olarak yoğun bakım [Intensive care unit as a stressor]. Yaşam Becerileri Psikoloji Dergisi [Life Skills Journal of Psychology] 2018;2(4):207-214.
21. Özdemir N, Saygı C. Yoğun bakim hastalarinda görülen anksiyetede hemşirelik yaklaşimi [Nursing approach to anxiety in intensive care patients]. International Journal on Mathematics, Engineering \& Natural Sciences.2019;9:23-31.

22. Sidar A, Dedeli Ö, İskesen Aí. Açık kalp cerrahisi öncesi ve sonrası hastaların kaygı ve ağrı distresi: ağı düzeyi ile ilişkisinin incelenmesi [The relationship between anxiety, pain distress and pain severity before and after open heart surgery in patients]. Dahili ve Cerrahi Bilimler Yogun Bakim Dergisi [Turkish Journal of Medical and Surgical Intensive Care Medicine]. 2013;4:1-8.

23. Assis de Barros JK, Siuves A. Stressors in intensive care units: Strategies for humanization of care. Hospice \& Palliative Medicine International Journal 2018;2 (6):378-384. DOI: 10.15406 / hpmij.2018.02.00129.

24. Celik S. Yoğun bakım hastalarında ağrı yönetimi [Pain management in intensive care patients]. Yoğun Bakım Hemşireliği Dergisi [Journal of Intensive Care Nursing] 2016;20(1):1-8.

25. Uslu Y, Demir Korkmaz F. Intensive care patients sleep and nursing role. Journal of Education and Research in Nursing 2015;12 (3):156-161. DOI: 10.5222/HEAD.2015.156.

26. Miranda-Ackerman RC, Lira-Trujillo $M$, Gollaz-Cervantez AC et al. Associations between stressors and difficulty sleeping in critically ill patients admitted to the intensive care unit: A cohort study. BMC Health Serv Res. 2020;20:631. DOI: 10.1186/ s12913-020-05497-8.

27. Kayrakci F, Ozsaker E. Determination of the surgical patients' satisfaction levels from nursing care. Florence Nightingale Journal of Nursing 2014;(22)2:105-113.

28. Yildiz T, Onler E, Baskan B, Koluacik B, Malak A, Ozdemir A, Aydin Yilmaz H. Determination of hospitalized patients' satisfaction level with nursing services in surgical units. Int J Basic Clin Med. 2014;2(3):123-30. 